Egyptian Journal of Aquatic Biology \& Fisheries

Zoology Department, Faculty of Science,

Ain Shams University, Cairo, Egypt.

ISSN $1110-6131$

Vol. 23(3): $329-345$ (2019)

www.ejabf.journals.ekb.eg

\title{
Effect of heavy metals on the ovary of Tilapia zillii in some canals of Nile Delta
} area, Egypt.

\author{
Ahmad M. Azab ${ }^{1}$; Mohamed A. Aly-Eldeen ${ }^{2}$; Hassan M. M. Khalaf-Allah ${ }^{1}$ and \\ Mohamed M. A. El-Battal ${ }^{1}$ \\ 1. Marine Biology and Ichthyology Branch, Zool. Dept., Fac. Sci., Al-Azhar Univ., Cairo, Egypt \\ 2. National Institute of Oceanography and Fisheries, Lab. of Marine Chemistry, Egypt
}

\section{ARTICLE INFO}

\section{Article History:}

Received: Aug. 6, 2019

Accepted: Aug. 21, 2019

Online: Aug. 23, 2019

\section{Keywords:}

Tilapia zillii

Heavy metals

Ovary

Atresia

Histopathology

Nile Delta

Egypt

\section{ABSTRACT}

Untreated or poorly treated industrial wastes, heavy metals and other pollutants are released into the Nile Delta canals network; causes accumulation of various heavy metals in the fish from sediments, water and food. The present study aimed to evaluate the effect of heavy metals on the ovary of Tilapia zillii in some River Nile canals, at Nile Delta, Egypt. A total of 502 specimens of adult Tilapia zillii were monthly collected from Zifta, Shubra Malakan and El-Nasria stations at El-Gharbia Governorate, during the period from December, 2017 to November, 2018. Heavy metals $(\mathrm{Cu}, \mathrm{Pb}, \mathrm{Ni}$, and $\mathrm{Cd})$ were measured in the ovary of the fish at three stations. Histopathological changes in the ovary were photographed and described.

Results showed that the highest annual averages value of heavy metals concentrations in the ovary of $T$. zillii were recorded at El-Nasria station, followed by Shubra Malakan station and reached to its lowest value at Zifta station. The mature oocytes in the ovaries of Tilapia zillii had the highest value $(74.43 \%)$ at Zifta, medium value $(49.87 \%)$ in the ovaries fish at Shubra Malakan and lowest value $(15.07 \%)$ in the ovaries of fish at ElNasria. The percentage of mature oocytes decreases and atresia increases with increase heavy metals concentrations. Therefore, stopping of maturation was noticed in some ovaries of fish collected from El-Nasria station (with the highest heavy metals concentrations).

The histopathological features in the ovaries of $T$. zillii, collected from Shubra Malakan and El-Nasria stations showed degenerative and necrotic changes in the oocytes and proliferative changes in most oocyte's granulosa. The ovarian cells of $T$. zillii converted to testicular cells. The histopathological alterations observed in the ovary may be attributed to the effects of heavy metals in the agricultural, industrial and sewage wastes discharged into El- Nasria station at Omar Bey Drainage.

This study concluded that the increase in heavy metals causes increased atresia in the ovary Tilapia zillii. Therefore, the technical treatment must be made to the agricultural, industrial and sewage wastes discharged into Omar Bey Drainage.

\section{INTRODUCTION}

The Nile River considered as one of the major sources of fish production in Egypt, since it constitutes $23.3 \%$ of the total fish production of natural sources in Egypt (GAFRD, 2015). The Nile River branches and tributaries are the main sources 
of drinking and irrigation waters for Nile Delta including, El-Qalubia, El-Gharbia, ElDakahlia and Damietta Governorates. The River Nile receives a large amount of effluents of mostly untreated agricultural, domestic and industrial waste waters (Zyadah, 1996; Abdo, 2004 and El-Amawy, 2016).

Environmental pollution is considered as one of the most serious problems that faced mankind in the $20^{\text {th }}$ century and still require great efforts at all levels, nationally and internationally. This is especially true with respect to rivers pollution, because they serve as recipient of urban, rural and industrial waste waters which contain frequently hazardous contaminants in rather high concentrations (Zyadah, 1999).

El-Gharbia Governorate is the central part of the Nile Delta and extends along wide area of more than $1943.5 \mathrm{~km}^{2}$. The area is bounded on the West by the Rosetta branch and on the East by the Damietta branch. The Governorate extends into Kafr El-Sheikh in the north and Monofiya Governorate in the south. It consists of eight centers; all of them are cultivated lands and densely populated (Sakr \& Mabrouk, 2006 and El-Amawy, 2016). The excessive uses of sewage effluent and sludge, overfertilization, over-use of manures for irrigation purposes cause hazardous effects on plants, animals and human health. In addition, discharge of liquid or solid wastes with different kinds of contaminants into the geologic environment causes groundwater deterioration (Zeidan, et al., 2015).

The contamination by heavy metals is one of the real problem which human was exposed, can cause harmful effect on air, water, soil, plants and human health. Industrial waste, chemical structure of land and metal of mining can be considered as source of heavy metal pollution in aquatic environment (Vinodhini \& Narayanan, 2008).

Fish are comparatively positioned at the top of food chain in aquatic environments; consequently they can accumulate various heavy metals from sediments, water and food (Yilmaz et al., 2007; Zhao et al., 2012; Sthanadar et al., 2013 and El-Amawy, 2016).

Tilapia zillii was distributed in most tropical and subtropical regions and provides $70 \%$ of African fish production. It was concentrated mainly in the shallow inshore regions, high tolerance to salinity, omnivores and used in aquatic weed control. T. zillii was nest builders; fertilized eggs are guarded in the nest by a brood parent (Anene, 2005; El-Sayed, 2006; Ahmad et al., 2015 and Adams, 2016).

The heavy metals decreased the reproductive parameters (Alne-Na-Ei \& Rady, 1998; Khallaf et al., 2003; Khalaf-Allah \& Shehata, 2011 and Ciftci et al., 2015) and many histopathological changes were recorded in the ovary of fishes (Mohamed, 2003; Mazrouh \& Mahmoud, 2009; Shobikhuliatul et al., 2013 and Ambani, 2015).

Therefore, the present study aimed to evaluate the effect of some heavy metals (copper, lead, nickel and cadmium) on the ovary of Tilapia zillii, collected from different localities of Delta Nile River (Zifta station at Damietta Branch; Shubra Malakan station at Bahr Shebeen Canal and El- Nasria station at Omar Bey Drainage).

\section{MATERIALS AND METHODS}

\section{Fish specimens' collection:}

A total of 502 specimens of adult Tilapia zillii were collected monthly from different localities of River Nile tributaries at El-Gharbia Governorate; 164 specimens of Zifta station at Damietta Branch $(11.5-22.8 \mathrm{~cm}$ in total length and 32$235.4 \mathrm{~g}$ in total weight); 162 specimens of Shubra Malakan station at Bahr Shebeen 
Canal (11-24 cm in total length and 35-205 $\mathrm{g}$ in total weight) and 176 specimens of El- Nasria station at Omar Bey Drainage) $(11.5-23.5 \mathrm{~cm}$ in total length and 35-206 g in total weight), formed the materials for the present study during the period from December, 2017 to November, 2018. Gill net, trammel net (Dabba, El-Mehhaier or Shebak El-Dak) and basket traps (Gwabi) were the main fishing methods used to collect the fish. Fishes were freshly examined and preserved in $10 \%$ formalin solution and transported to the laboratory of Marine Biology in Zoology Department, Faculty of Science, Al-Azhar University. In the laboratory, fishes were identified according to Bishai \& Khalil (1997). Total and standard lengths were measured to the nearest millimeter and recorded. Fish were also weighted to the nearest $0.1 \mathrm{~g}$ and then the following studies were carried out.

Determination of heavy metals in the fish ovary:

Fish samples at three stations were seasonally collected, stored in prewashed polyethylene bags and transferred immediately to the laboratory in ice box at $4^{\circ} \mathrm{C}$. In the laboratory, fishes were identified and all morphological characters for each sample were recorded. Fishes were dissected and the ovary was removed, then an exact weight $(0.5 \mathrm{~g})$ was placed in Teflon vessel and $5 \mathrm{ml}$ of nitric acid (ultrapure) was added to soft organs. The vessels were tightly covered and allowed to predigest at room temperature overnight. Samples were digested on a hot plate at $100{ }^{\circ} \mathrm{C}$ for 2 hrs. then cooled at room temperature. If the solution was not clear, it was reheated for another $1 \mathrm{hr}$. at $100 \circ \mathrm{C}$. The samples were transferred to $25 \mathrm{ml}$ volumetric flasks. Before analysis, samples were filtered. All samples were analyzed three times for $\mathrm{Cu}$, $\mathrm{Pb}, \mathrm{Ni}$, and $\mathrm{Cd}$ by using flame atomic absorption spectrometry (model Varian AA240FS) according to the corresponding wave lengths (UNEP et al., 1984). Concentrations were expressed in terms of wet weight as microgram per gram according to the following equation:

Final results $(\mu \mathrm{g} / \mathrm{g}$ wet $\mathrm{wt})=$. conc. of element in digest solution $(\mu \mathrm{g} / \mathrm{l}) \times \mathrm{Vol}$. of digest solution $(\mathrm{ml})$.

Histopathological techniques:

For histopathological techniques, specimens of Tilapia zillii at three stations were dissected, ovaries were removed and examined. Ovaries were cut into small pieces ( $5 \mathrm{~mm}$ thick) and fixed immediately in alcoholic Bouin`s fluid for at least 48 hours, dehydrated in ascending concentrations of ethyl alcohol, cleared in xylene and embedded in paraplast wax (M.P.: $58^{\circ} \mathrm{C}$ ). Transverse sections were cut at the thickness of 4-6 $\mu \mathrm{m}$, stained with Harris`s haematoxylin and eosin for general structure (Humason, 1979). The staining slides were observed by light microscope (XSZ-N107T) at different magnifications, then photographed using Digital Camera (Toup Cam, Ver. 3.7) and described.

On the basis of the histopathological differences, the atretic oocytes may be classified according to Cupta \& Matti (1986).

\section{RESULTS}

\section{Heavy metals in fish ovary: \\ Copper:}

Results in Table (1) revealed that, the highest annual average value of copper concentrations in ovary of $T$. zillii is records at El-Nasria station $(11.87 \pm 3.03 \mu \mathrm{g} / \mathrm{g}$ wet wt.), followed by Shubra Malakan station $(8.52 \pm 0.99 \mu \mathrm{g} / \mathrm{g}$ wet wt.) and reached to its lowest value $(5.73 \pm 0.54 \mu \mathrm{g} / \mathrm{g}$ wet wt. $)$ at Zifta station. 
The concentration of copper in the ovary of $T$. zillii is varied considerably from season to season. At Zifta station, the maximum value of copper concentrations is records during winter $(6.23 \pm 1.03 \mu \mathrm{g} / \mathrm{g}$ wet wt. $)$ and the minimum $(5.25 \pm 0.22 \mu \mathrm{g} / \mathrm{g}$ wet wt.) occurred during spring. At Shubra Malakan station, the copper concentrations ranges between $5.72 \pm 0.37 \mu \mathrm{g} / \mathrm{g}$ wet wt. during spring to $9.96 \pm 0.62$ $\mu \mathrm{g} / \mathrm{g}$ wet wt. during summer. At El-Nasria station, the highest value of copper concentration $(15.6 \pm 1.13 \mu \mathrm{g} / \mathrm{g}$ wet wt.) is records during winter and the lowest $(8.2$ $\pm 0.81 \mu \mathrm{g} / \mathrm{g}$ wet wt.) occurred during autumn (Table 1 ).

Lead:

Results in Table (1) revealed that, the highest annual average value of lead concentrations in ovary of $T$. zillii is records at El-Nasria station $(31.50 \pm 2.70 \mu \mathrm{g} / \mathrm{g}$ wet wt.), followed by Shubra Malakan station $(26.40 \pm 6.64 \mu \mathrm{g} / \mathrm{g}$ wet wt.) and reached to its lowest value $(8.92 \pm 1.13 \mu \mathrm{g} / \mathrm{g}$ wet wt. $)$ at Zifta station.

The concentration of lead in ovary of $T$. zillii is varied considerably from season to season. At Zifta station, the maximum value of lead concentrations is records during spring $(10.09 \pm 0.52 \mu \mathrm{g} / \mathrm{g}$ wet wt. $)$ and the minimum $(7.44 \pm 1.57 \mu \mathrm{g} / \mathrm{g}$ wet wt.) occurred during summer. At Shubra Malakan station, the lead concentrations ranges between $19.96 \pm 0.84 \mu \mathrm{g} / \mathrm{g}$ wet wt. during autumn to $32.24 \pm 1.92 \mu \mathrm{g} / \mathrm{g}$ wet wt. during winter. At El-Nasria station, the highest value of lead concentration (33.67 $\pm 6.98 \mu \mathrm{g} / \mathrm{g}$ wet wt.) is records during winter and the lowest $(28.11 \pm 5.33 \mu \mathrm{g} / \mathrm{g}$ wet wt.) occurred during autumn (Table 1).

Nickel:

Results in Table (1) revealed that, the highest annual average value of nickel concentrations in muscles and ovary of $T$. zillii is records at El- Nasria station (17.62 $\pm 4.18 \mu \mathrm{g} / \mathrm{g}$ wet wt.), followed by Shubra Malakan station $(16.11 \pm 2.57 \mu \mathrm{g} / \mathrm{g}$ wet wt.) and reached to its lowest value $(5.45 \pm 0.89 \mu \mathrm{g} / \mathrm{g}$ wet wt.) at Zifta station.

The concentration of nickel in ovary of $T$. zillii is varied considerably from season to season. At Zifta station, the maximum value of nickel concentrations is records during winter $(6.65 \pm 0.78 \mu \mathrm{g} / \mathrm{g}$ wet wt. $)$ and the minimum $(4.53 \pm 0.53 \mu \mathrm{g} / \mathrm{g}$ wet wt.) occurred during summer. At Shubra Malakan station, the nickel concentrations ranges between $12.45 \pm 1.53 \mu \mathrm{g} / \mathrm{g}$ wet wt. during autumn to $18.30 \pm$ $0.85 \mu \mathrm{g} / \mathrm{g}$ wet wt. during winter. At El-Nasria station, the highest value of nickel concentration $(22.18 \pm 2.18 \mu \mathrm{g} / \mathrm{g}$ wet wt.) is records during spring and the lowest $(12.10 \pm 2.61 \mu \mathrm{g} / \mathrm{g}$ wet wt.) occurred during autumn (Table 1$)$.

\section{Cadmium:}

The highest annual average value of cadmium concentration in ovary of $T$. zillii is records at Shubra Malakan Station $(0.57 \pm 0.11 \mu \mathrm{g} / \mathrm{g}$ wet wt. $)$, followed by ElNasria Station $(0.55 \pm 0.23 \mu \mathrm{g} / \mathrm{g}$ wet wt.) and reached to its lowest value $(0.43 \pm 0.05$ $\mu \mathrm{g} / \mathrm{g}$ wet wt.) at Zifta Station (Table 1).

The concentration of cadmium in ovary of $T$. zillii is varied considerably from season to season. At Zifta station, the maximum value of cadmium concentrations is records during spring $(0.48 \pm 0.10 \mu \mathrm{g} / \mathrm{g}$ wet wt. $)$ and the minimum $(0.35 \pm 0.18 \mu \mathrm{g} / \mathrm{g}$ wet wt.) occurred during summer. At Shubra Malakan station, the cadmium concentrations ranges between $0.45 \pm 0.18 \mu \mathrm{g} / \mathrm{g}$ wet wt. during autumn to $0.70 \pm 0.10$ $\mu \mathrm{g} / \mathrm{g}$ wet wt. during spring. At El-Nasria station, the highest value of cadmium concentration $(0.87 \pm 0.16 \mu \mathrm{g} / \mathrm{g}$ wet wt.) is records during summer and the lowest $(0.35 \pm 0.28 \mu \mathrm{g} / \mathrm{g}$ wet wt.) occurred during spring (Table 1$)$. 
Table 1: Concentrations of heavy metals ( $\mu \mathrm{g} / \mathrm{g}$ wet wt. $\pm \mathrm{SD})$ in ovary of Tilapia zillii, collected from different localities of Delta Nile River, during the period from December, 2017 to November, 2018.

\begin{tabular}{|c|c|c|c|c|c|c|}
\hline $\begin{array}{l}\text { Heavy } \\
\text { metals }\end{array}$ & Station Season & Winter & Spring & Summer & Autumn & $\begin{array}{l}\text { Annual } \\
\text { Average }\end{array}$ \\
\hline \multirow{3}{*}{$\mathbf{C u}$} & Zifta & $6.23 \pm 1.03$ & $\mathbf{5 . 2 5} \pm 0.22$ & $\mathbf{6 . 1 8} \pm 0.71$ & $\mathbf{5 . 2 8} \pm 0.03$ & $\mathbf{5 . 7 3} \pm 0.54$ \\
\hline & Shubra Malakan & $\mathbf{9 . 9 4} \pm 0.02$ & $\mathbf{5 . 7 2} \pm 0.37$ & $\mathbf{9 . 9 6} \pm 0.62$ & $\mathbf{8 . 4 7} \pm 0.59$ & $\mathbf{8 . 5 2} \pm 0.99$ \\
\hline & El- Nasria & $\mathbf{1 5 . 6} \pm 1.13$ & $\mathbf{1 1 . 5 5} \pm 1.60$ & $\mathbf{1 2 . 1 3} \pm 1.80$ & $\mathbf{8 . 2 0} \pm 0.81$ & $\mathbf{1 1 . 8 7} \pm 3.03$ \\
\hline \multirow{3}{*}{$\mathbf{P b}$} & Zifta & $\mathbf{8 . 7 5} \pm 0.40$ & $\mathbf{1 0 . 0 9} \pm 0.52$ & $\mathbf{7 . 4 4} \pm 1.57$ & $\mathbf{9 . 4 1} \pm 3.59$ & $\mathbf{8 . 9 2} \pm 1.13$ \\
\hline & Shubra Malakan & $\mathbf{3 2 . 2 4} \pm 1.92$ & $\mathbf{3 2 . 0 3} \pm 4.15$ & $\mathbf{2 1 . 4 0 \pm 1 . 5 3}$ & $\mathbf{1 9 . 9 6} \pm 0.84$ & $26.40 \pm 6.640$ \\
\hline & El- Nasria & $\mathbf{3 3 . 6 7} \pm 6.98$ & $32.96 \pm 12.52$ & $\mathbf{2 9 . 4 8} \pm 1.45$ & $\mathbf{2 8 . 1 1} \pm 5.33$ & $\mathbf{3 1 . 0 5} \pm 2.70$ \\
\hline \multirow{3}{*}{$\mathbf{N i}$} & Zifta & $6.65 \pm 0.78$ & $\mathbf{5 . 1 3} \pm 0.60$ & $\mathbf{4 . 5 3} \pm 0.53$ & $\mathbf{5 . 5 0} \pm 0.20$ & $\mathbf{5 . 4 5} \pm 0.89$ \\
\hline & Shubra Malakan & $\mathbf{1 8 . 3 0} \pm 0.85$ & $16.30 \pm 3.80$ & $\mathbf{1 7 . 4 0} \pm 1.30$ & $\mathbf{1 2 . 4 5} \pm 1.53$ & $\mathbf{1 6 . 1 1} \pm 2.57$ \\
\hline & El- Nasria & $18.76 \pm 5.82$ & $22.18 \pm 2.18$ & $\mathbf{1 7 . 4 5} \pm 1.50$ & $12.10 \pm 2.61$ & $\mathbf{1 7 . 6 2} \pm 4.18$ \\
\hline \multirow{3}{*}{ Cd } & Zifta & $\mathbf{0 . 4 5} \pm 0.13$ & $\mathbf{0 . 4 8} \pm 0.10$ & $\mathbf{0 . 3 5} \pm 0.18$ & $\mathbf{0 . 4 3} \pm 0.10$ & $\mathbf{0 . 4 3} \pm 0.05$ \\
\hline & Shubra Malakan & $\mathbf{0 . 6 0} \pm 0.10$ & $\mathbf{0 . 7 0} \pm 0.10$ & $\mathbf{0 . 5 2} \pm 0.10$ & $\mathbf{0 . 4 5} \pm 0.18$ & $\mathbf{0 . 5 7} \pm 0.11$ \\
\hline & El- Nasria & $\mathbf{0 . 5 3} \pm 0.21$ & $\mathbf{0 . 3 5} \pm 0.28$ & $\mathbf{0 . 8 7} \pm 0.16$ & $\mathbf{0 . 4 3} \pm 0.15$ & $\mathbf{0 . 5 5} \pm 0.23$ \\
\hline
\end{tabular}

\section{Ovary of Tilapia zillii:}

\section{Morphology of ovary Tilapia zillii:}

The Morphology of ovary T. zillii collected from Zifta station at Damietta Branch showed normal structure. The ovaries are paired, elongated structures and circular in cross section. It was recognized by clear fluid beneath the ovarian epithelium and the oocytes appear yellowish in color (Figure 1).

The Morphology of ovary T. zillii collected from Shubra Malakan station at Bahr Shebeen Canal showed mild abnormal. The ovary was recognized by batches of clear brownish fluid beneath the ovarian epithelium and the oocytes appear reddish in color (Figure 1).

The Morphology of ovary T. zillii collected from El-Nasria station at Omar Bey Drainage showed abnormal shape. The ovary was recognized by clear greenish fluid beneath the ovarian epithelium and the oocytes appear dark in color with appearance of white spots on the ovary wall. Females have external abnormalities such as skin ulcers and discoloration (Figure 1).
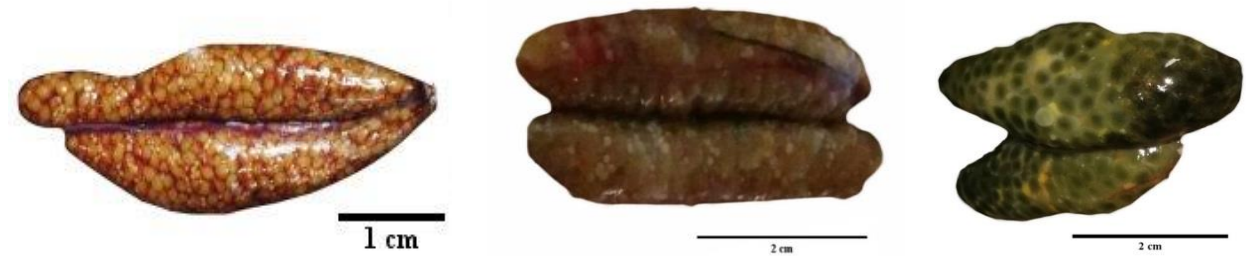

Fig. 1: The Morphology of ovary T. zillii collected from Zifta station (left), Shubra Malakan station (mid) and El- Nasria station (right)

\section{Relation between oocyte maturation and atresia:}

Data in Table (2) showed that the highest percentage of mature oocytes $(74.43 \%$ of the total number of oocytes) is records in the ovaries Tilapia zillii at Zifta station. This value decreased to $49.87 \%$ in the fish ovaries at Shubra Malakan station and reaching to its lowest value $(15.07 \%)$ in the fish ovaries at El-Nasria station. The maximum percentage of immature oocytes (17.22\% of the total number of oocytes) is records in the fish ovaries at Zifta station. This value decreased to $9.77 \%$ in the fish ovaries at Shubra Malakan station and reaching to its minimum percentage $(5.08 \%)$ in the ovaries fish at El-Nasria Station. The lowest percentage of atretic oocytes $(8.35 \%$ of the total number of oocytes) is records in the fish ovaries at Zifta station. This percentage of atresia increased to $40.36 \%$ in the fish ovaries at Shubra Malakan station and reached to its highest value 
(79.85\%) in the fish ovaries at El-Nasria station.

Table 2: The mature oocytes (\%), immature oocytes (\%) and atretic follicles (\%) in the ovaries of T. zillii, collected from different localities of Delta Nile River, during the period from December, 2017 to November, 2018

\begin{tabular}{cccc}
\hline Station & Mature (\%) & Immature (\%) & Atresia (\%) \\
\hline Zifta & 74.43 & 17.22 & 8.35 \\
Shubra Malakan & 49.87 & 9.77 & 40.36 \\
El-Nasria & 15.07 & 5.08 & 79.85 \\
\hline
\end{tabular}

\section{Relation between maturity stages and atresia:}

Data in Table (3) showed that, no atretic oocytes were found in previtellogenesis of $T$. zillii at all stations. However, early-vitellogenesis contained small percentages of atretic oocytes at Shubra Malakan station (7\%), El-Nasria station $(16 \%)$ and absent at Zifta station. In the mature phase (mid-vitellogenesis, latevitellogenesis and pre-spawning), the percentages of ovarian atresia were absent at Zifta station, low range (20-32\%) at Shubra Malakan station and marked higher range (53-70\%) at El-Nasria station. In spawning stage, however, the lowest percentage of atretic oocytes $(8 \%)$ was recorded at Zifta station, it increased gradually at Shubra Malakan station (22\%) and reached to the highest value (64\%) at El-Nasria station.

Table 3: Atretic oocytes (\% of total number of oocytes) in relation to different ovarian stages of $T$. zillii, collected from different localities of Delta Nile River, during the period of study.

\begin{tabular}{lccc}
\hline \multirow{2}{*}{ Maturity stages } & \multicolumn{3}{c}{ Station } \\
\cline { 2 - 4 } & Zifta & Shubra Malakan & El-Nasria \\
\hline Pre-vitellogenesis & - & - & - \\
Early-vitellogenesis & - & $\mathbf{7 \%}$ & $\mathbf{1 6 \%}$ \\
Mid-vitellogenesis & - & $\mathbf{2 0 \%}$ & $\mathbf{5 3 \%}$ \\
Late-vitellogenesis & - & $\mathbf{2 5 \%}$ & $\mathbf{6 2 \%}$ \\
Pre-spawning & - & $32 \%$ & $70 \%$ \\
Spawning & $8 \%$ & $22 \%$ & $64 \%$ \\
\hline
\end{tabular}

\section{Histopathology of ovary Tilapia zillii:}

The histological features in the ovary of $T$. zillii collected from Zifta station at Damietta Branch showed the normal structure (Figure 2A). In spawning stage, the ripe oocytes are known to be prevailing in the ovaries occur immediately before ovulation. They are characterized by the enormous size of oil droplets which were coalescence and usually formed one large droplet which located in the central part of the oocyte. The yolk globules appeared to be fused together. Consequently the yolk material appeared as a homogeneous mass (homogenized yolk globules). The membranes enclosing the egg proper are comparatively thin (Figure $2 \mathrm{~B}$ ).
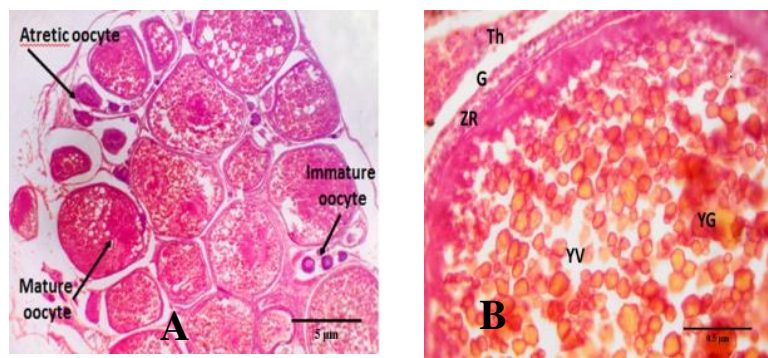

Fig. 2: A: T.S. in the ovary of T. zillii, collected from Zifta station and showed normal structure (H-E, Scale bar $=5 \mathrm{um}$ ). B: Enlarged portion of T. S. in the ovary of T. zillii, collected from Zifta station and showed mature oocyte contain yolk vesicle (YV), yolk granules (YG) and the wall of oocyte consists of theca $(\mathrm{Th})$, granulosa $(\mathrm{G})$ and zona radiata $(\mathrm{ZR})(\mathrm{H}-\mathrm{E}$, Scale bar $=0.5$ um). 
The histopathological examination to the ovary of $T$. zillii collected from Shubra Malakan station at Bahr Shebeen Canal showed less features of abnormal ovary structure (Figure 3A). Several histopathological changes were observed. The microscopic observation showed degenerative changes (atresia) in some oocytes and proliferative changes in the granulosa of some oocytes, resulting in adhesion of its cellular coat. Besides, some oocytes collapsed and became abnormally irregular in shape. In addition, separation of the follicular layers from the oocytes was observed (Figure 3A).

The histopathological examination to the ovary of T. zillii collected from ElNasria station at Omar Bey Drainage showed more features of abnormality. The oocytes are mostly in the early stages of maturity; the oocytes were not developed and stopped in maturation (Figure 3B).

The histopathological changes included degenerative and necrotic changes in the oocytes, proliferative changes in the granulosa of most oocytes, resulting in adhesion of the cellular coat of oocytes. The abnormal ripe oocyte with homogenous yolk material and corrugated disrupted follicular sheath, lysing of yolk material, remain of rupture ripe follicles in inter follicular spaces together with degenerated small oocytes were noticed (Figure 3C).

Sex disturbance was observed in the ovary of $T$. zillii collected from ElNasria station at Omar Bey Drainage. Testicular tissues were detected as seminiferous lobules in some fish ovaries of this station (Figure 3D).
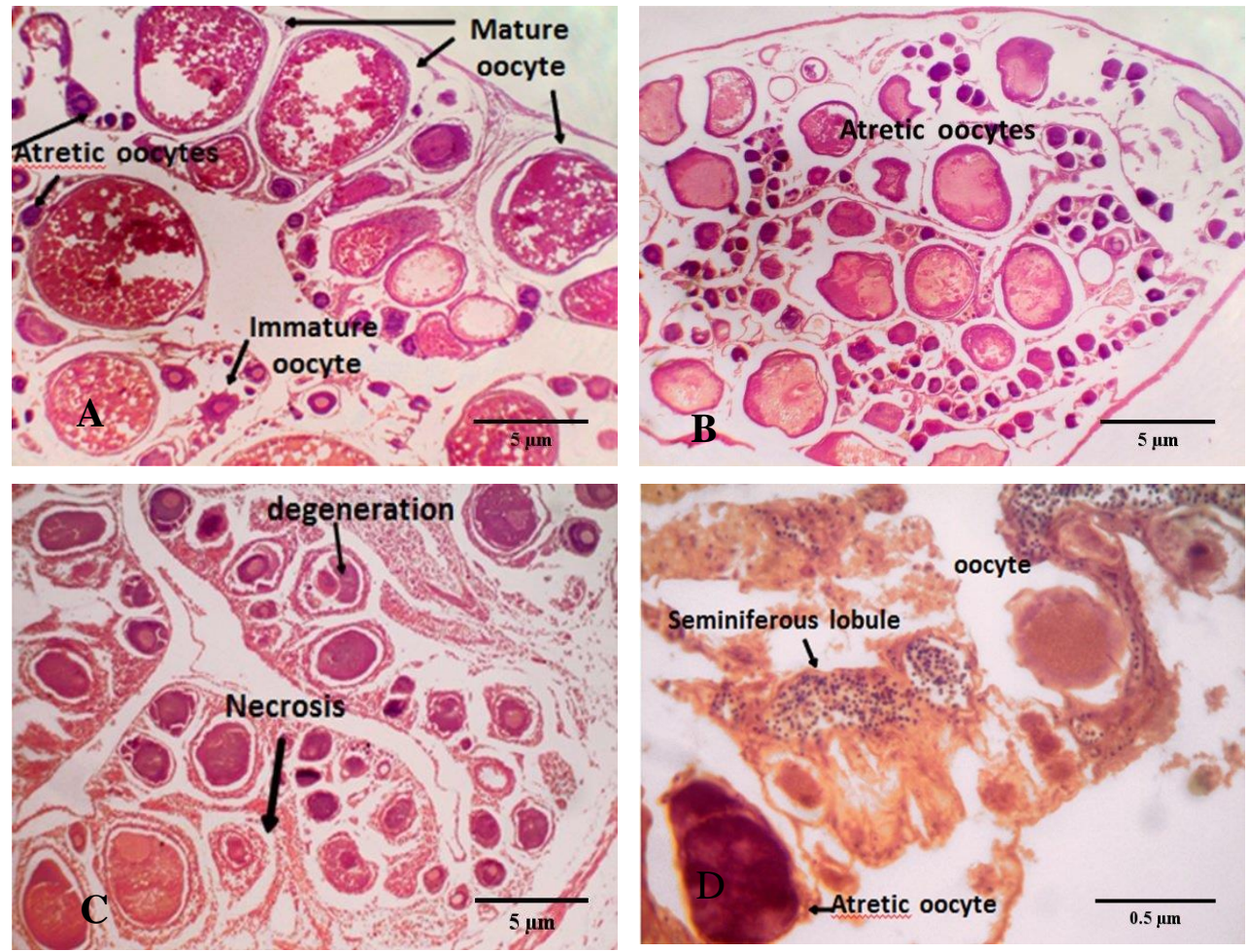

Fig. 3: T.S. in the ovary of T. zillii, collected from Shubra Malakan station (A) and El-Nasria station (B, C \& D) showing the abnormal structure of ovary, atretic follicles and appearance of testicular tissues (H-E; A, B and C: Scale bar $=5$ um, D: Scale bar $=0.5 \mathrm{um}$ ).

\section{Atresia:}

Histological examination to the ovary of $T$. zillii collected from Shubra Malakan and El-Nasria stations revealed that, the atretic oocytes are derived from either vitellogenic oocytes or mature oocytes that did not further develop but degenerated and reabsorbed in examined specimens. However, follicular atresia was 
noticed to takes place in the following way: the follicular epithelium is converted from squamous to the columnar pattern with no distinct boundaries between cells and their nuclei become rounded. The striation of the zona radiata of the oocyte had disappeared. Isolated ruptures appeared in it initially and then all of it soon breaks into isolated pieces. The cells of the follicular epithelium are apically emarginated with the oocyte and evidently function in the case as phagocytes. The follicular phagocytic cells invade the yolky materials of the oocytes. The yolky materials exhibit clear signs of deformation and the nuclei of the oocytes disappear. The phagocytic cells when invaded the oocyte had attacked the proteins at first, while the carbohydrates and lipids were still within the theca which still remained surrounding the oocytes till the completion of its reabsorption (Figure 4).

On the basis of the histopathological differences, the atretic oocytes may be classified into two main types: nonbursting and bursting atresia.

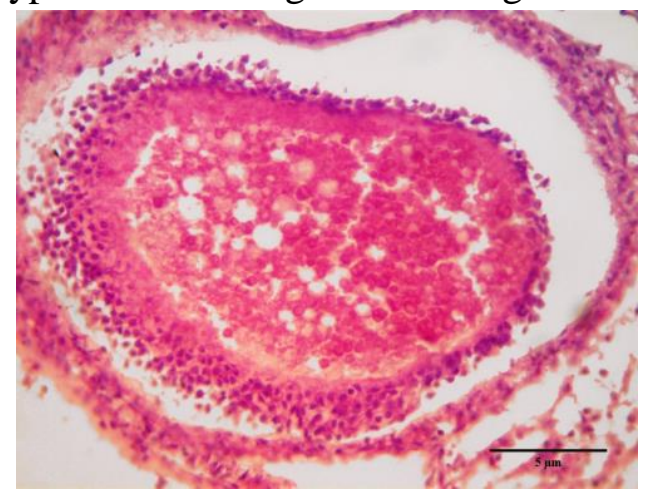

Fig. 4: T.S. in the ovary of T. zillii, collected from El-Nasria station showed that the follicular epithelium is converted from squamous to the columnar pattern with no distinct boundaries between cells and their nuclei become rounded $(\mathrm{H}-\mathrm{E}$, Scale bar $=5 \mathrm{um})$.

\section{Non-bursting atresia:}

This type of atresia is very common in the early oocytes. It is characterized by the non-ruptured follicular wall and can be classified into three types:

\section{Capsulated atresia:}

It characterized by a drastic reduction in the size of ooplasm which appeared as a dark stain mass. As the process of atresia proceeds, the cells of the stratified epithelium increase in number and invade the underlying liquefied yolk. In more advanced stage of atresia, the whole yolky mass becomes loose and intermixes with invading follicular cells. Moreover, the theca folliculi becomes highly vascular and increase markedly in the thickness. In late period of atresia, the atretic follicle loses its vascularity and appears as an empty sac which is resorbed through ovarian stroma (Figure 5A).

\section{Lipoidal atresia:}

The follicular wall looked crumpled and nearly thick. The ooplasm loaded with vacuoles which may be lipoid materials. In late lipoidal atresia the oocyte membrane wrinkled and become thick (Figure 5B).

\section{Cystic atresia:}

The oocyte lost its normal identity and reduced in size leaving a wide clear previtelline space between the ooplasm and the oocyte membrane (Figure 5C).

\section{Bursting atresia:}

This type of atresia was observed in the late developmental oocytes. It is characterized by the ruptured follicular wall and can be classified into five types: 

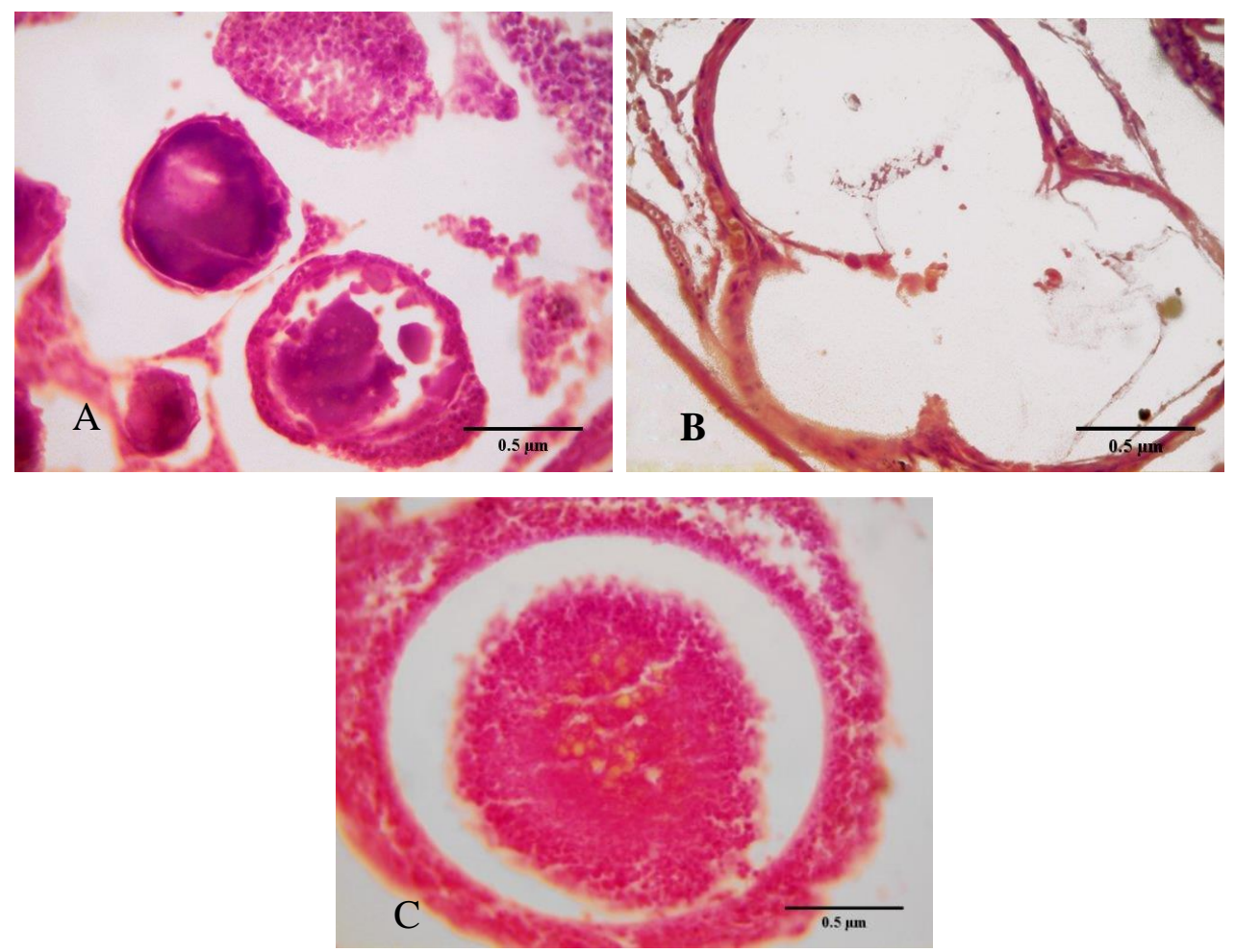

Fig. 5: T.S. in the ovary of T. zillii, showing non-bursting atresia (H-E)

(A) Capsulate atresia appears as a dark stain.

(B) Lipoidal atresia with vacuoles (V).

(C) Cystic atresia with reduction in size and previtelline space between zona radiate (ZR) and oocyte content $(\mathrm{OC})$. (H-E; Scale bar $=0.5 \mathrm{um})$.

\section{Multiple bursts:}

Atretic follicles are protruding at several regions of follicles. The wall of oocyte was thicker than the normal one (Figure 6A).

\section{Single bursts:}

In the atretic oocytes the bursting site is single and the contents of the follicle extruded into the stroma. The wall of atretic oocyte appeared thick (Figure 6B).

\section{Liquefied bursts:}

Atretic follicles of this type are contained large vacuoles in the ooplasm and the wall of oocyte was thick and wrinkled in the late stages (Figure 6C).

\section{Phagocytic bursts:}

In this type, the follicle cells transformed into phagocytic cells, that invade the ooplasm through the ruptured parts of follicular wall. They showed reduction in size and gradual degeneration (Figure 6D).

\section{Advanced phagocytic bursts:}

The phagocytic cells invade the ooplasm through the ruptured parts of follicular wall and separate the oocytes into two or three small portions and degeneration (Figure 6E). Finally, all forms of atretic oocytes degenerated and disappeared in the stroma.

\section{Abundance (\%) of atresia types in different stations:}

Data in Table (4) showed that non-bursting atresia only is records in the ovary T. zillii at Zifta Station. The non-bursting atresia represented by capsulated atresia which records by the highest percentage $(46.67 \%)$. It decreases gradually in lipoidal atresia $(33.33 \%)$ and reached to its lowest value (20\%) in cystic atresia. 
Non-bursting and bursting atresia is records in the ovary T. zillii at Shubra Malakan Station. The non-bursting atresia represented by capsulated atresia $(10.45 \%)$, lipoidal atresia $(17.91 \%)$ and cystic atresia $(8.96 \%)$. The bursting atresia attains lowest percentage $(2.98 \%)$ in multiple bursts. It increases gradually in single bursts $(5.97 \%)$, followed by liquefied bursts $(14.92 \%)$ and reached to its highest percentage in phagocytic bursts $(29.85 \%)$. In addition to $8.96 \%$ in advanced phagocytic bursts (Table 4).
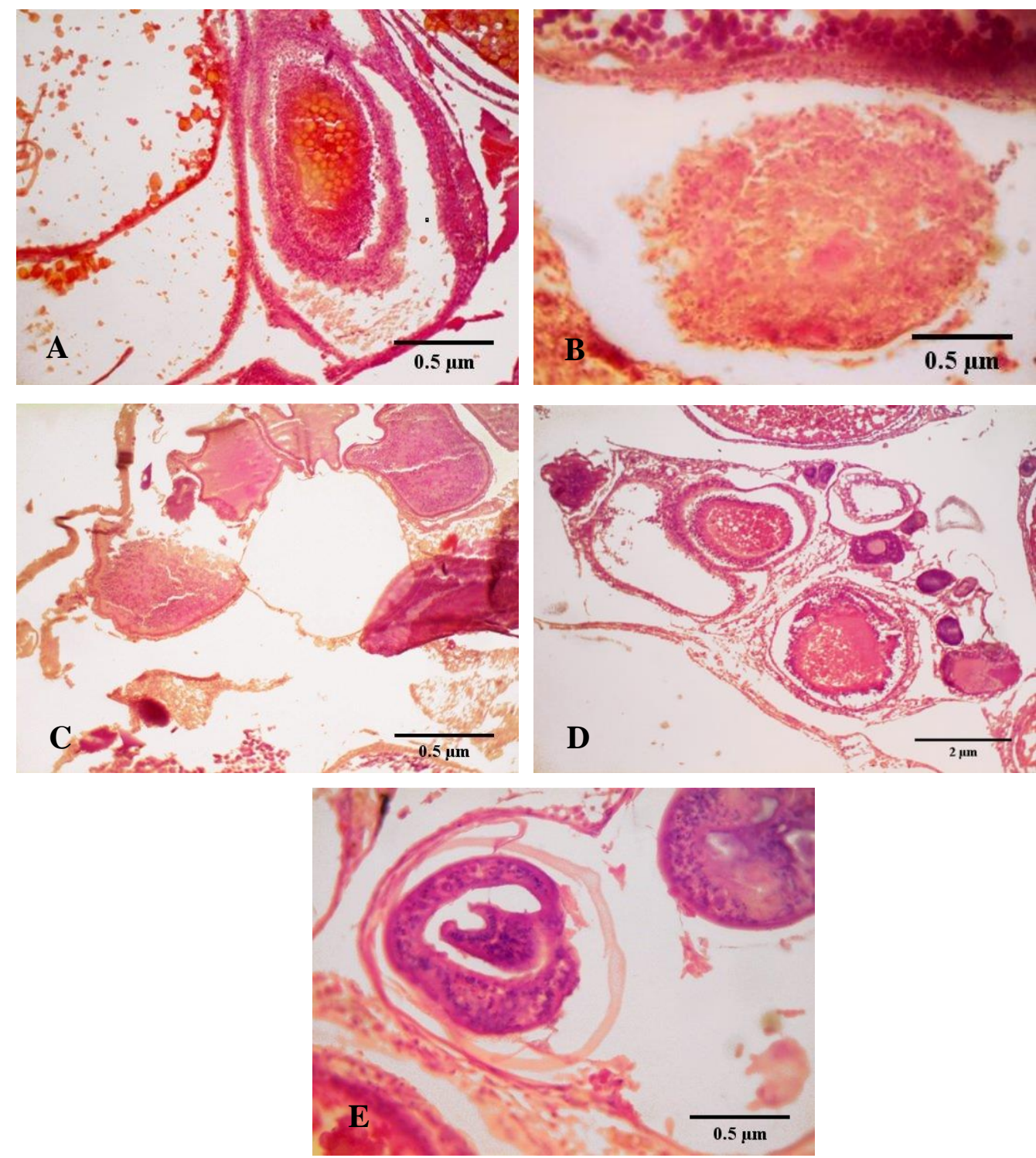

Fig. 6: T.S. in the ovary of T. zillii, showing the bursting atresia

(A) Multiple bursts; the ooplasm loaded with vacuoles (V) between zona radiate (ZR) and oocyte content (OC) (H-E).

(B) Single bursts; the oocyte content (OC) extruded into the stroma (S) (H-E).

(C) Liquified bursts; the ooplasm loaded with vacuoles (V) (H-E).

(D) Phagocytic bursts; with reduction in size and gradual degeneration (H-E).

(E) Advanced phagocytic bursts; with degeneration (H-E).

(A,B, C and E: Scale bar $=0.5$ um; D: Scale bar $=2$ um).

In El- Nasria Station, Non-bursting and bursting atresia is records in the ovary T. zillii. The non-bursting atresia represented by few percentages in capsulated atresia $(1.57 \%)$ and lipoidal atresia $(4.72 \%)$. The bursting atresia attains lowest percentage in multiple bursts $(0.79 \%)$. It increases progressively in single bursts $(2.36 \%)$, followed 
by liquefied bursts $(6.30 \%)$ and reached suddenly to its highest percentage in phagocytic bursts $(70.87 \%)$. In addition to $13.39 \%$ in advanced phagocytic bursts (Table 4).

Table 4: Abundance (\%) of different types of atresia in the ovary of $T$. zillii, collected from different canals of Delta Nile River, during the period from December, 2017 to November, 2018

\begin{tabular}{|c|c|c|c|c|}
\hline \multirow{2}{*}{ No } & \multirow{2}{*}{ Types of atresia } & \multicolumn{3}{|c|}{ Station } \\
\hline & & Zifta & Shubra Malakan & El- Nasria \\
\hline $\mathbf{1}$ & Capsulation & $46.67 \%$ & $10.45 \%$ & $1.57 \%$ \\
\hline 2 & Lipoidal & $33.33 \%$ & $17.91 \%$ & $4.72 \%$ \\
\hline 3 & Cystic & $20 \%$ & $8.96 \%$ & - \\
\hline 4 & Multiple bursts & - & $2.98 \%$ & $0.79 \%$ \\
\hline 5 & Single bursts & - & $5.97 \%$ & $2.36 \%$ \\
\hline 6 & Liquefied bursts & - & $14.92 \%$ & $6.30 \%$ \\
\hline 7 & Phagocytic bursts & - & $29.85 \%$ & $70.87 \%$ \\
\hline 8 & Advanced Phagocytic bursts & - & $8.96 \%$ & $13.39 \%$ \\
\hline
\end{tabular}

\section{DISCUSSION}

Fishes are often the top of aquatic food chain and may concentrate large amount of some metals such as lead, cadmium, copper, zinc, mercury and iron. These metals accumulate differently in fish organs (kidney, brain, muscles, gills, gonads and liver) (Gomaa et al., 1995; Zyadah, 1995; El-Enani, 2004; Ghanem et al., 2015 and ElAmawy, 2016).

Fish can be considered as one of the most significant indicators in freshwater systems for the estimation of pollution level. Tilapia zillii is one of the aquatic organisms affected by heavy metals, so it was frequently used as a metal biological marker in toxicological studies. Heavy metals can also adversely affect the growth rate of fishes. The presence of heavy metals in different foods constitutes a serious health hazards depending on their relative levels (Mansour \& Sidky, 2002).

Studies were focused on bioaccumulation of heavy metals in different parts of edible fish such as ovary. In the present study, the highest annual average value of copper, lead, nickel and cadmium concentrations in the ovary of T. zillii was recorded at El- Nasria station, followed by Shubra Malakan station and reached to its lowest value at Zifta station. The elevation of heavy metals concentrations in the ovary of $T$. zillii collected from El- Nasria station may be due to Omar Bey Drainage contaminated with heavy metals, pesticides, insecticides, fertilizers, possible domestic/industrial wastes, and other chemicals. Similar findings were recorded by El-Amawy (2016).

Accumulations of copper, lead, nickel and cadmium in the ovary of T. zillii showed visible variations among the three stations of study at El-Gharbia Governorate with the highest concentrations of lead, followed by nickel, copper and cadmium in the ovary. The higher accumulation in the ovary may alter the levels of various biochemical parameters thereby affecting the function of its vitello-genesis and development of maturity stages.

Reproduction is the most critical function in aquatic animals affected by chronic toxicant stress (Birge et al., 1985). The ovaries of female fishes that fail to spawn become atretic shortly after the spawning period (Guraya, 1994). Ovarian atresia of female fishes has been suggested to associate with several factors, including overcrowding and heavy metal concentration (Levavi-sivan et al., 2004); higher temperature (Saxena \& Sandhu, 1994 and Pankhurst et al., 1996); paucity of males (Tripple \& Harvey, 1990); elevated pesticide (Sukumar \& Karpaganapathy, 1992); 
dietary deficiencies (Kjesbu et al., 1991 and Cerda et al., 1995); cyanide compounds (Alne-Na-Ei, 1997); confinement of fishes (Coward et al., 1998); sediment contamination (Alne-Na-Ei \& Rady, 1998); spawning success (Levavi-sivan et al., 2004) and polluting chemicals or global warming (Unal et al., 2007).

In the present study, the morphology of ovary $T$. zillii collected from Zifta station was recognized by clear fluid beneath the ovarian epithelium and the oocytes appear yellowish in color. In the fish sample collected from Shubra Malakan station, the ovarian atresia was recognized by batches of clear brownish fluid beneath the ovarian epithelium and the oocytes appear reddish in color. While in the fish sample collected from El- Nasria station the ovarian atresia was recognized by clear greenish fluid beneath the ovarian epithelium and the oocytes appear blackish in color with appearance of white spot on the ovary wall. This may be due to low, medium and high concentrations of heavy metals in the ovary T. zillii collected from Zifta, Shubra Malakan and El-Nasria stations respectively.

This result was agreement with Alne-Na-Ei \& Radi (1998) and Khalaf-Allah \& Shehata (2011). They mentioned that the ovarian atresia caused by heavy metals and recognized by batches of clear brownish fluid beneath the ovarian epithelium and the oocytes appear reddish in color.

In the present study, the percentages of mature oocytes in the ovaries Tilapia zillii were highest (74.43\%) at Zifta station (low heavy metals), medium (49.87\%) in the ovaries fish at Shubra Malakan station (medium heavy metals) and low (15.07\%) in the ovaries fish at El- Nasria station (high heavy metals). While, the percentages of atretic oocytes were lowest $(8.35 \%)$ in the ovaries fish at Zifta station, medium $(40.36 \%)$ in the ovaries fish at Shubra Malakan station and high $(79.85 \%)$ in the ovaries fish at El- Nasria station. This means that the maturation oocytes increases and atresia decreases with lowest heavy metals and the vise verse, the maturation oocytes decreases and atresia increases with highest heavy metals. Similar results were detected by Ambani (2015).

Generally, the contaminated water and sediment has been suggested to cause potential adverse effects such as reduced growth, impaired reproductive success, backbone degradation, enlarged livers and tumor fin (Lesko et al., 1996). According to Munkittrick \& Leatherland (1984), the heavy metals stress may cause a dysfunction of the hypothalamic-pituitary-gonad axis, which prevents the release of mature eggs, but not their development or maturation or ovarian atresia and spawning failure of the goldfish may be related to dysfunction in the timing of gonadotropin release or possibly related to the fact that steroid production, which is under gonadotropic regulation, is inappropriate for needs of normal gonad maturation, ovulation and spawning. The disturbance in the ovary functions of the fish exposed to water contaminated with heavy metals was documented by Alne-Na-Ei \& Radi (1998) and Khalaf-Allah \& Shehata (2011).

In the present study, according to maturity stages, the percentages of ovarian atresia were absent at Zifta station, low range $(20-32 \%)$ at Shubra Malakan station and marked higher range $(53-70 \%)$ at El-Nasria station. These findings were confirmed with Lowerre-Barbier et al. (1996) and Khalaf-Allah \& Shehata (2011). They reported that the atretic follicles occur at any stage of development. Kurita et al. (2003) and Ramadan \& El-Halfawy (2007) stated that, atresia has been noted to be wide spread in latter phases of maturation process and associated with a valuable energy resources and environmental conditions.

But, this disagreed with Simonsen \& Gundersen (2005). Who reported that, atresia was highest in early phases of maturation in green land halibut but relatively 
high levels of atresia were also observed in fish in more advanced maturity phases. Mousa et al. (2005) mentioned that metallothionein may store the essential metals (zinc and copper) in the ovary wall of Oreochromis niloticus in Lake Manzalah (polluted area) and release to function as cofactors for enzymes involved in oogenesis. The atretic oocyte stage may be due to displacement of essential metals (zinc and copper) by non-essential metals (cadmium and lead). The chronic heavy metals exposure may cause toxic effects on granulosa cells, which changed from steroid secreting cells to phagocytic cells.

In the present study, stopping of maturation was noticed in some ovaries fish collected from El-Nasria station (high heavy metals).The stop of maturation may be due to adverse effect of heavy metals on sex hormones of fish. It may be attributed to the effects of the agricultural, industrial and sewage wastes discharge into El-Nasria station at Omar Bey Drainage. This result was matching with Ambani (2015). This of course affects the wild fish community as a result of reproductive disorder and leads to serious histopathological alternation of vital organs in fishes.

In the present study, the histopathological features of ovary Tilapia zillii collected from Shubra Malakan station showed atresia. The microscopic observation showed degenerative changes (atresia) in some oocytes and proliferative changes in the granulosa of some oocytes, resulting sometimes in adhesion of the cellular coat of the oocytes. Besides, some oocytes collapsed and became abnormally irregular in shape. Similarly, the histopathological alterations observed in the ovaries were in agreement with those observed by Mohamed (2003).

In the present study, the histopathological features of ovary Tilapia zillii collected from El- Nasria station at Omar Bey Drainage showed advanced atresia. The histopathological changes included degenerative and necrotic changes in the oocytes, proliferative changes in the granulosa of most oocytes, resulting sometimes in adhesion of the cellular coat of the oocytes. Therefore, the histopathological alterations observed in the ovary may be attributed to the effects of heavy metals in the agricultural, industrial and sewage wastes discharge into Omar Bey Drainage. Similar results were detected by Ambani (2015). Mazrouh \& Mahmoud (2009) mentioned that the gonads of Oreochromis niloticus from Rosetta Branch exposed to higher concentrations of pollutants showed higher incidence of gonadal abnormalities in the form of deformed oocytes and spermatocytes with reduction in their numbers and lack of active oogenesis and spermatogenesis.

In the present study, the ovarian cells (oocytes) of $T$. zillii converted to testicular cells (sperm mother cells). It may be due to Omar Bey Drainage heavily loaded with pollution, especially heavy metals. This result was matching with the result obtained by Shobikhuliatul et al. (2013). He observed that the presence of abnormalities testis-ova in gonad of Puntius javanicus, which indicated the occurrence of intersex of this species. The greater attention needs to be given to xenobiotic pollutants and endocrine disrupting chemicals problems.

Atresia occurs when oocytes abort to develop and fail to be spawned from the ovary and then are resorbed back into the gonad (Arrocha, 2002). In the present study, histological examination in the ovaries fish collected from Shubra Malakan and El- Nasria stations showed that, the atretic oocytes may be classified into two main types: nonbursting and bursting atresia. Kamel (1990) classified the atretic follicles according to the diameters, but in the present study, classification depended on the histological descriptions. The same results were obtained by Ramadan \& ElHalfawy (2007) and Khalaf-Allah \& Shehata (2011). They indicated that, 
deformation of the wall of oocytes was considered as the first step of atresia and then phagocytosis of oocytes.

The present study showed that nonbursting atresia was very common in the early oocytes. It is characterized by the non-ruptured follicular wall and can be classified into three types: capsulated, lipoidal and cystic atresia. Similar results were obtained by Ramadan \& El-Halfawy (2007) and Khalaf-Allah \& Shehata (2011).

The present study showed that bursting atresia was observed in the late developmental oocytes. It is characterized by the ruptured follicular wall and can be classified into five types: multiple bursts, single bursts, liquefied bursts, Phagocytic bursts and advanced phagocytic bursts. Ramadan \& El-Halfawy (2007) and KhalafAllah \& Shehata (2011) recorded four types. Our study depend on histological examination suggested advanced phagocytic bursts.

In the present study, non-bursting atresia was recorded only by low percentage in the ovary T. zillii at Zifta station. Non-bursting and bursting atresia was recorded by low percentage at Shubra Malakan station. In El- Nasria station, Non-bursting was recorded by low percentage and bursting atresia was recorded by highest percentage in the ovary T. zillii. It may be due to highest concentrations of heavy metals in ElNasria station at Omar Bey Drainage

This study concluded that, Atresia needs further investigation to understand the mechanism and significance of atresia to fish behavior.

\section{CONCLUSION}

The increase in heavy metals causes increased atresia in the ovary Tilapia zillii. Therefore, the technical treatment must be made to the agricultural, industrial and sewage wastes discharged into Omar Bey Drainage.

\section{REFERENCES}

Abdo, M. H. (2004). Environmental studies on the River Nile at Damietta branch region, Egypt. J. Egypt. Acad. Soc. Environ. Develop. (D- Environmental Studies), 5 (2): 85 104.

Adams, A. (2016). Studies on the food and feeding habits, condition factors of Tilapia Zilli in Tiga Dam, Kano State, Nigeria, 1 (2): 53 - 63.

Ahmad, M.K.; Baba, H.A.; Haruna, M.A.; Bichi, A.H.; Abubakar, S. and Danba, E.P. (2015). Some aspects of the biology of Tilapia zilli in Kanye Dam, Kabo Local Government, Kano State, Nigeria. International Journal of Agriculture, Forestry and Fisheries, 3(2): 32-36.

Alne-Na-Ei, A.A. (1997). Deleterious effects of cyanide compounds used by some fishermen on the economic fishes of Bahr Shebeen Canal, Egyptian Delta. 1st. conference of Egypt. J. Aquat. Biol. \& Fish ., 1(2): 199- 231.

Alne-Na-Ei, A.A. and Rady, M.I. (1998). Ecological studies on the cat fish, Chrysichthys rueppelli, in the Nile tributary with notes on the factors influencing the ratio of ovarian atresia. J. Union Arab Biol, Cairo, 10 (A): 467-488.

Ambani, M.M. (2015). Effects of reproductive biology on heavy metal pollution on the histopathological structure of gonads in India., 3 (2): 223 -227. 
Anene, A. (2005). Condition factor of four cichlid species of a man-made lake in Imo state, Southeastern Nigeria. Tur. J. Fish. Aquat. Sci., 5: 43-47.

Arocha, F. (2002). Oocyte development and maturity classification of swordfish from the north-western Atlantic. J. Fish Biol., 60: 13 - 27.

Birge, W.J.J.; Black, A. and Westerman, A.G. (1985). Short-term fish and amphibian embryo-larval tests for determining the effects of toxicant stress on early life stages and estimating chronic values for single compounds and complex effluents. Environ. Toxicol. Chem., 4: 807- 822.

Bishai, H.M. and Khalil, M.T. (1997). Fresh Water Fishes of Egypt. Publications of National Biodiversity Unit, No. 9, Pp: 299.

Cerda, J.; Zanuy, S.; Carrillo, M.; Ramos, J. and Serrano, R. (1995). Short- and long-term dietary effects on female sea bass (Dicentrarchus labrax), seasonal changes in plasma profiles of lipids and sex steroids in relation to reproduction. Comp. Bioch. Phys., III (1): 83-91.

Ciftci, N.; Ay, O.; Karayakar, F.; Cicik, B. and Erdem, C. (2015). Effects of zinc and cadmium on condition factor, hepatosomatic and gonadosomatic index of Oreochromis niloticus. Fresenius Environmental Bulletin, 24 (11): 1-4.

Coward, K.L.; Bromage, N.R. and Little, D.C. (1998). Inhibition of spawning and associated suppression of sex steroid levels during confinement in the substratespawning Tilapia zillii. J. Fish. Biol., 52(1): 152-165.

Cupta, S.K. and Matti, R.R. (1986). Study of atresia in the ovary during the annual reproductive cycle and nesting cycle of the Pied myna. J. Morphol., 190: 285 - 296.

El-Amawy, A.A.B. (2016). EEffect of some pollutants on quality and water characters of the River Nile at Tanta and Kafr El-Zayat, Egypt. M.Sc. Thesis, Fac. Sci., Al-Azhar Univ. Egypt, pp: 470.

El-Enani, H.R. (2004). Ecological and biological studies on Lake El-Manzala with special reference to their water quality and sediment productivity. M. Sc. Thesis, Fac. Sci., Al Azhar Univ. Egypt, pp: 358.

El-Sayed, A.M. (2006). Tilapia Culture. CABI Publishing (ed.)., Cambridge, USA., Pp: 277.

GAFRD (General Authority for Fish Resources Development) (2015). General Authority for Fish Resources Development. Annual fishery statistics book, Cairo, Egypt.

Ghanem, M.H.M.; Shehata, S.M.; Abu-Zaid, M.M.; Abdel-Halim, A.M. and Abbas, M.M. (2015). Accumulation of some heavy metals in the muscles of Diplodus sargus, inhabiting El-Mex Bay (Alexandria, Mediterranean Sea) with special references to its physiological responses. Int. J. Environ. Sci. Engineer., 6: 1-13.

Gomaa, M. N. E.; Abou-Arab, A. A. K.; Badawy, A. and Naguib, K. (1995). Distribution pattern of some heavy metals in Egyptian fish organs. Food chem., 53: 385-389.

Guraya, S.S. (1994). Gonadal development and production of gametes in fish. Proc. Indian Nation. Sci. Acad., 60 (1): 15-32.

Humason, G.L. (1979). Animal tissue techniques, fourth edition. Freeman, W.H. and company (eds.), San Francisco, pp: 659.

Kamel, S.A.M. (1990). Study of atresia in the ovary of the Nile bolti, Orechromis niloticus during its annual reproductive cycle. Proc. Zool. Soc. A.R.E., 18.

Kjesbu, O.S.; Klungsoyr, J. and Kryvi, H. (1991). Fecundity, atresia and egg size of captive Atlantic cod (Gadus morhua) in relation to proximate body composition. Can. J. Fish. Aquat. Sci., 48 (12): 2333-2343.

Khalaf Allah, H.M.M. and Shehata, S.M.A (2011). Report on state of atresia in the ovaries of some Mediterranean Sea fishes from the Egyptian coast, Al-Azhar Bull. Sci. Vol. 22, No. 1 (June): pp. $1-12$.

Khallaf, E.A.; Galal, M. and Authman, M. (2003). The biology of Oreochromis niloticus in a polluted canal. Ecotoxicology, 12 (5): 405-416.

Kurita, Y.; Meier, S. and Kjesbu, O.S. (2003). Oocyte growth and fecundity regulation by atresia of Atlantic herring, Clupea harengus in relation to body condition throughout the maturation cycle. J. Sea Res., 49: 203 - 219. 
Lesko, L.T.; Smith, S. B. and Blouin, M.A. (1996). The effect of contaminated sediment on fecundity of the Brown Bullhead in three Lake Erie tributaries. J. Great Lake Res., 22 (4): 830-837.

Levavi-Sivana, B.; Vaimana, R.; Sachsb, O.; Tzchorib, I. (2004). Spawning induction and hormonal levels during final oocyte maturation in the silver perch, Bidyanus bidyanus. Aquaculture, (229): 419 - 431.

Lowerre-Barbieri, S.K.; Chittnden, J.R. and Barbieri, L.R. (1996). The multiple spawning patterns of weak fish in the Chesapeake Bay and Middle Atlantic Bight. J. Fish Biol., 48: $1139-1163$.

Mansour, S.A. and Sidky, M.M. (2002). Ecotoxicological studies. 3. Heavy metals contaminating water and fish from Fayoum Governorate, Egypt. Food Chem., 78: 1522.

Mazrouch, M.M.; Mahmoud, H.H. (2009). Some aspect of reproductive biology with emphasis on the effect of pollution on the histopathological structure of gonads in Oreochromis niloticus from Rosetta Branch, Nile River, Egypt. World J. Fish. Mar. Sci., 1(3):190-198.

Mohamed, F.A.S. (2003). Histopathological studies on some organs of Oreochromis niloticus, Tilapia zillii and Synodontis schall from El-Salam Canal, Egypt. Egypt. J. Aquat. Bio. Fish., 7 (3): 99- 138.

Mousa, M. A.; El-Gamal, A. E. and Khalil, N. A. (2005). Metallothionein as a biomarker of environmental metal contamination and its implication in the reproduction of the Nile Tilapia, Oreochromis niloticus (Teleostei, Cichlidae). Egypt J. Aquat. Biol. \& Fish., 9 (4): 309- 331.

Munkittrick, K.R. and Leatherland, J. F. (1984). Abnormal pituitary-gonad functionin in two feral populations of goldfish, Carassius auratus (L.), suffering epizootic of an ulcerative disease. J. Fish diseas, 7: 433 - 447.

Pankhurst, N.W.; Purser, G.J.; Kraak, G.V., Thomas, P.M. and Forteath, G. N. R. (1996). Effect of holding temperature on ovulation, egg fertility, plasma levels of reproductive hormones and in vitro ovarian steroidogenesis in the rainbow trout, Ohcorhynchus mykiss. Aquacul., 146 (3-4): 277-290.

Ramadan, A.M. and El-Halfawy, M.M. (2007). Common forms of atresia in the ovary of some Red Sea fishes during reproductive cycle. Pakistan J. of Biological Science, 1 6.

Saxena, P.K. and Sandhu, R. (1994). Influence of temperature on ovarian recrudescence in the Indian catfish, Heteropneustes fossilis. J. Fish Biol., 44(1): 168-171.

Sakr, M.A. and Mabrouk, B.M. (2006). Environmental Assessment and Controls of groundwater quality, El-Gharbiya Governorate, Egypt, a better environment in Delta area, Tanta University, Egypt.

Shobikhuliatul, J.J.; Andayani, S.; Couteau, J.; Risjani, Y. and Minier, C. (2013). Some aspect of reproductive biology on the effect of pollution on the histopathology of gonads in Puntius javanicus from Mas river, Surabaya, Indonesia. J. Biol. Life Sci., 4(2):191-205.

Simonsen, C.S. and Gundersen, A.C. (2005). Ovary development in halibut, Reinhardtius hippoglossoides in West Green Land waters. J. Fish Biol., 67: 1299 - 1317.

Sthanadar, I.A.; Sthanada, A. A.; Yousaf, M.; Muhammad, A. and Zahid, M. (2013). Bioaccumulation profile of heavy metals in the gills tissue of Wallago attu (MULLEY) from Kalpani River Mardan, Khyber Pakhtunkhwa Pakistan. Int. J. Biosci. 3: 165-174.

Sukumar, A. and Karpaganapathy, P.R. (1992). Pesticide-induced Atresia in ovary of a fresh water fish, Colisa lalia (Hamilton-Buchanan).Bull. Environ. I Cont. Toxicol., 48 (3): 457- 462.

Trippel, E.A. and Harvey, H.H. (1990). Ovarian atresia and sex ratio imbalance in white sucker, Catostomus commersoni. J. Fish Biol., 231- 239.

Unal, G.; Turkoglu, V.; Oguz, A.R. and Kaptaner, B. (2007). Gonadal histology and some biochemical characteristics of Chalcalburnus tarichi (Pallas, 1811) having abnormal gonads. Fish Physiol. Biochem., 33: 153-165. 
UNEP (United Nations Environment Program); FAO (Food and Agriculture Organization); IAEA (International Atomic Energy Agency) and IOC (International Olympic Committee) (1984). Sampling of selected marine organisms and sample preparation for trace metal analysis. Reference Methods for Marine Pollution Studies No. 7, Rev. 2, UNEP, Nairobi.

Vinodhini, R. and Narayanan, M. (2008). Bioaccumulation of heavy metals in organs of freshwater fish, Cyprinus carpio. J. Environ. Sci. Tech., 5: 179-182.

Yilmaz, F.; Özdemir, N.; Demirak, A. and Levent, T.A. (2007). Heavy metal levels in two fish species Leuciscus cephalus and Lepomis gibbosus. Food Chem., 100: 830 - 835.

Zeidan, B.A.; Aly, A.I.M; Rashwan, I.M.H.; Ahmed, M.A. and Ghoraba, S.M. (2015). Scenarios for groundwater remediation using n15 in Nile Delta. Eighteenth International Water Technology Conference, IWTC18 Sharm ElSheikh.

Zhao, S.; Feng, C.; Quan, W.; Chen, X.; Niu, J. and Shen, Z. (2012). Role of living environments in the accumulation characteristics of heavy metals in fishes and crabs in the Yangtze River Estuary, China. Mar. Pollut. Bull., 64: 1163-1171.

Zyadah, M. (1995). Environmental impact assessment of pollution in Lake Manzalah and its effect on fishes. Ph. D. Thesis, Fac. Sci., Mansoura Univ. Egypt. Pp: 127.

Zyadah, M. (1996). Occurrence of heavy metals in some fish sediment and water samples from River Nile within Damietta Governorate. Proceeding $6{ }^{\text {th }}$ international conference environment protection is a must, Alex, Egypt. 929 - 942.

Zyadah, M. (1999). Accumulation of some heavy metals in Tilapia zillii organs from Lake Manzalah, Egypt, Tr. J. of Zool., 23: 365 - 372.

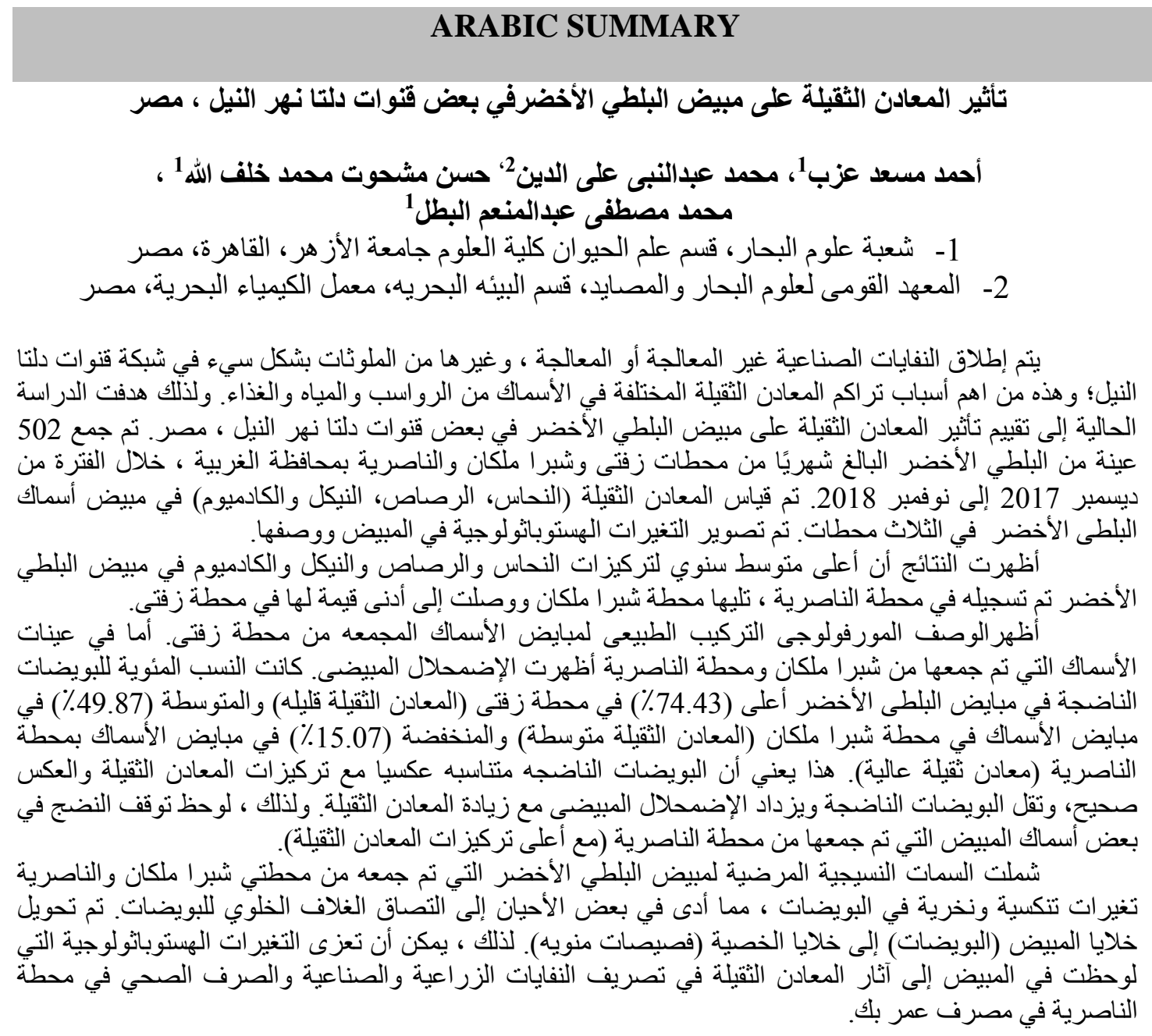

